We can but regret both the decreasing zeal in home committees for the gathering and preserving of memorabilia of our lost boys, and our department want of means wherewith to increase our own achievements, as time assuages grief and tends to erase thought of their sacred sacrifice.

\title{
EDWARD JOHNSTONE'S CHARACTER AND HISTORY
}

The unique and elaborate character sketch of Edward Johnstone published in this issue of the Annals was written in longhand over thirty years ago and deposited in the Historical Department of Iowa. It is of almost as much interest because of the author as of the great man described. Dr. J. M. Shaffer was himself a man of great activity and influence in the formative period of the new state of Iowa. His work as physician, as lecturer at the Keokuk College of Physicians and Surgeons, as surgeon of the board of enrollment of men entering the Union Army from the First Congressional District, as secretary of the Iowa State Agricultural Society in its early years, as state senator, as a lifelong student of science and natural history, as a collector of specimens, and as one helpful to Charles Aldrich in researches in early Iowa history and in founding the Historical Department of Iowa-all these things have already been set out in the Annals twenty and thirty years ago. But an accurate and connected account of Edward Johnstone has never been published in the Annals. E. H. Stiles in his "Recollections and Sketches," and B. F. Gue in his "History of Iowa," both give good sketches of his life, Gue's being nearer complete. Sam M. Clark in the Gate City at the time of the death of Mr. Johnstone, gave extended biographical material and the "History of Lee County, Iowa," Western Historical Company, Chicago, 1876, also contains considerable framgentary matter about him.

This article by Dr. Shaffer is more of a characterization than a biography. It glows with the warmth of personal friendship, and delineates personal qualities that cause the reader to know Judge Johnstone, the man, more accurately than a plain recital 
of facts could show. Yet we believe a brief and connected biographical outline should be given.

Edward Johnstone was born in Westmoreland County, Pennsylvania, July 4, 1815, and died at Keokuk, Iowa, May 17, 1891. He was one of a family of ten children, eight brothers and two sisters. Each of the eight sons was over six feet tall and weighed over 200 pounds. The eldest two were graduated from West Point. His brother William F. became governor of Pennsylvania, serving from 1848 to 1852 and with great credit. ${ }^{1}$ Both Mr. Gue and Mr. Stiles state that one of the other brothers became governor of California. This is apparently an error, although James Neely Johnson was governor of California in 1856 to $1858,{ }^{2}$ but he spelled his name differently from Edward Johnstone's family, and was from southern Indiana. The father of Edward, Alexander Johnstone, a remarkable man, died in 1872 in his one hundredth year.

Edward Johnstone studied law, was admitted to the bar and in 1837, at the age of twenty-two, removed to Burlington, then Wisconsin Territory. The Second Session of the Legislative Assembly of Wisconsin Territory met at Burlington, November 6, 1837, and on November $8 \mathrm{Mr}$. Johnstone was elected and sworn in as one of the three "transcribing clerks" of the House of Representatives. $^{3}$ On January 16, 1838, the assembly passed an act requiring all persons claiming land in the half-breed tract to file their claims with the clerk of the District Court of Lee County within one year, showing the nature of the title upon which they relied, and appointing Edward Johnstone, Thomas S. Wilson, and David Brigham commissioners to take testimony as to titles claimed by the respective parties at a per diem salary of $\$ 6.00 .^{4}$ Mr. Johnstone took up his residence at Montrose the spring of 1838 and remained there most of the time until the fall of 1839 discharging his duties in connection with this commission.

In $1839 \mathrm{Mr}$. Johnstone removed to Fort Madison and formed a partnership with General H. T. Reid for the practice of law. That year he was elected as one of the representatives from Lee

1"National Cyclopedia of American Biography," Vol. II, p. 288.

2Ibid, Vol. IV, p. 107 .

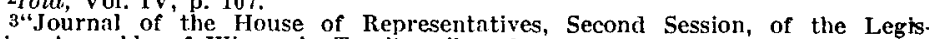
Iative Assembly of Wisconsin Territory," p. 29.

4"The Struggle for the Half-Breed Tract" by B. L. Wick, ANNALs of Iowa, Third Series, Vol. VII, p. 21.

5 "History of Lee County, Iowa," p. 700, 
County to the Second Legislative Assembly of the Territory of Iowa, which convened in Burlington, November 4, 1839. $\mathrm{Mr}$. Johnstone was elected speaker of the House, and was re-elected at the extra session which met the following summer.

In January, 1840, Mr. Johnstone wrote the first call for a Democratic territorial convention, and led the following list of signers: Edward Johnstone, Shepherd Leffler, Laurel Summers, Jos. T. Fales, G. S. Bailey, John B. Lash, Jacob L. Myers, Daniel Brewer, W. G. Coop, S. C. Hastings, J. M. Robertson, Jacob Minder, H. Van Antwerp, Thomas Cox, J. W. Parker. ${ }^{6}$ In 1840 he was elected a member of the Territorial Council and served in the Third and Fourth assemblies, the latter being the first assembly to convene at Iowa City.

President Polk appointed Mr. Johnstone in 1845 United States attorney for the territory of Iowa and he served until Iowa became a state. In 1849 he served as mayor of Fort Madison, and from 1851 to 1855 he was county judge of Lee County. In 1855 when George G. Wright was elected by the General Assembly as chief justice of the Supreme Court Mr. Johnstone received forty-five votes to fifty-three for Mr. Wright. The same year, 1855, he, with Governor Grimes and Charles S. Blake, were appointed to locate and superintend the erection of a state hospital for the insane. They selected Mount Pleasant as the place and directed the construction of the building. He was elected from Lee County a member of the Constitutional Convention of 1857, which framed our present constitution, and had a leading part in making that fundamental law.

On April 27, 1861, a few days after President Lincoln's first call for volunteers, a meeting of citizens was held at Fort Madison and Judge Johnstone presided. He was made chairman of a committee of five to raise relief funds for the families of the volunteers. The first company of soldiers organized at Fort Madison took the name of the "Johnstone Rifles" in honor of him."

In $1868 \mathrm{Mr}$. Johnstone removed to Keokuk where he organized and established the Keokuk Savings Bank, becoming cashier, which position he held until his death. In 1888 he was appointed a member of the Iowa Soldiers' Monument Commission. His last

6Gue's "History of Iowa," Vol. I, p. 204.

7 "Lee County History," p. 557. 
important public position was in 1890 when he was appointed the First District member of the Iowa Commission to the Columbian Exposition at Chicago. When the commission met in September he was elected its president, but died May 17, 1891 .

The great influence that Mr. Johnstone attained in the territory when he was so young indicates that, as some of his friends have said, he could have reached almost any position in public affairs in state or nation if his tastes and ambitions had led him on. When but little over twenty-four years of age he became speaker of the lower branch of the legislative assembly, and at the same age by general consent it was he who led in the call for the first Democratic convention in the territory which soon became the state. When such leadership was freely given to so young a man it must have been, as Dr. Shaffer intimates, because of his commanding ability, character, and personality.

The next day after his death the eloquent Sam M. Clark said editorially in the Keokuk Gate City, "The kingliest man in Iowa is dead."

\section{ABSTRACT OF THE MINUTES OF THE STATE BOARD OF CONSERVATION}

November 10, 1922

Motions.-Motions in substance as follows were passed: That all plans ffor the restoration of the barracks at Fort Atkinson be referred to the Board before construction is begun; that Mr. Harlan be authorized to spend not to exceed $\$ 30.00$ in photostatting government records touching matters of interest to the Board; that the improvement of the tract of land owned by the state between East Okoboji and Spirit lakes be deferred until April, 1923.

Resolutions.-Resolutions were adopted in substance as follows: That the local committee of Eldora who desire to establish a golf course on the margin of Eldora-Steamboat Rock Park, using a few acres of the park land therefor, be allowed to proceed with their plan of organization, and that they submit to the Board their proposed rules and a map of the proposed course showing the location and amount of park land they want to use; that T. F. Lynch of Pocahontas who desires to put in a cement dam or bulkhead to prevent the run-off from Lizard Lake, so as to maintain the water and preserve the lake, if he procure plans and specifications and assure the state against damage by the construction, that he be allowed to proceed, 
Copyright of Annals of Iowa is the property of State of Iowa, by \& through the State Historical Society of Iowa and its content may not be copied or emailed to multiple sites or posted to a listserv without the copyright holder's express written permission. However, users may print, download, or email articles for individual use. 